\title{
EVA as Superior Performance Measurement Tool
}

\author{
Abdullah Al Mamun, Shazali Abu Mansor \\ Faculty of Economics \& Business, University Malaysia Sarawak, Kota Samarahan, Malaysia \\ Email: mamun.abdullah84@yahoo.com
}

Received November 4, 2011; revised November 20, 2011; accepted December 9, 2011

\begin{abstract}
Prior to the East Asian financial crisis scholars found the necessity of a true financial performance measure in Malaysia. After more than one decade of the crisis Malaysian firms still stick with the conventional performance measures, which are criticised due to general accepted accounting principles. In this vein, this study aims to study a value based financial performance measure which can be adopted by the Malaysian firms over the conventional measures currently used. Economic Value Added (EVA) was introduced and advocated by Stern Stewart and Co. in 1982. This study intended to identify why EVA should be used as financial performance measure over the conventional measures and any added value or added advantage in EVA compare to conventional methods. EVA has been able to gain attention of the corporate giants like Coca-Cola, Sprint Corporation and Quaker Oats, as it is able to depict the true profitability of the company, however, there have been very little research conducted on EVA in Asian countries including Malaysia.
\end{abstract}

Keywords: Performance Measurement Tool; Economic Value Added (EVA); Value Based Measurement Tool; Malaysia; Conventional Measurement Tool

\section{Introduction}

Due to ample of evolution in last decade in the corporate world, managers and investors are seeking for an economic framework which better mirror the value and profitability of their company. Accounting tools which are being used till today are not sufficient and unlikely in facing the challenge arising from efficient capital markets and owners. Value based measurement framework, a new economic dimension is required, which could better reflect the opportunities and downsides. There are number of value based measurement in the economic framework, for example Economic Value Added (EVA), Cash Value Added (CVA), Cash Flow Return on Investments (CFROI), Shareholder Value Analysis (SVA) and Market Value Added (MVA) Erasmus, 2008 [1]; Maditinos, Sevic, \& Theriou, 2006 [2]; Fredrik, 1997 [3]. Any of these can be chosen by a company as their economic framework.

Company have to be very cautious in selecting their measurement tools, as it will affect substantially the management resources and every department of the company. The concept of economic framework is an innovative way to measure the value of a company. This economic measurement system determines companies' worth and performance based on their economic situation not according to accounting numbers produced using traditional accounting rules. According to the past studies, economic frameworks set quality standard in measuring performance and it is necessary for company to create value for shareholders.

\section{What Is Value Based Measurement System?}

Value based measurement has been argued as a major development tool comparing to the traditional financial performance measurement tools. According as, a company's cost of capital is taken into account in calculating whether there is value created of a firm (Erasmus, 2008). The inclusion of a firms' cost of capital in the calculation will determine whether or not value is created. An increase in shareholder's value is created if there is an excess of the returns results over the cost of capital in a firm Grant, 2003 [4]. These value based measurement tools are argued to be an attempt in overcoming the problems associated with the conventional measurement systems. From the available value based financial performance measurement tools EVA gains the most attention in the developed countries Worthington \& West, 2004 [5] and Erasmus, 2008.

However, though value based measurement has gained attention in the developed economies, it is said that the developing economies are still behind in using value based performance measures as firm performance measurement tools. Abdullah argued that in Malaysia, ratios are widely used by the companies in order to measure the firm performance, may not be able to measure and capture 
the firm's value which is created over the period. In fact, Malaysia is suffering from having a suitable performance measure tool which can help the investors to assess value created on their investment (Issham, 2011 [6]). In this vein, this study aims to evaluate the applicability of EVA which is a value based performance measurement tool, in Malaysia.

\section{What Is EVA?}

With reference to Anderson, Anne et al. (2005) [7] firms' earnings must exceed the cost of debt and equity, in order to create wealth, Hamilton (1777) [8] and Marshall (1890) [9]. It is argued that the origin of EVA was since Hamilton (1777) and Marshall (1890). In 1950s, the concept named as "residual income” was used by General Electric as performance measure.

In 1980s Stewart added a series of accounting adjustments based on GAAP figures and revised the computation of residual income (Geyser \& Liebenberg, 2003) [10]. New York based consulting firm Stern Stewart \& Co. named this concept as EVA and trademarked in 1989.

EVA has been defined in various ways. According to several scholars, EVA measures the difference between the return on company's capital and the cost of that capital (Dagogo \& Ollor, 2009 [11]; Young, 1997 [12]). EVA is "a measurement of the true economic profit generated by a firm” (Sharma \& Kumar, 2010 [13]; Stewart, 1994, pp. 73 [14]) and is calculated by comparing a firm's net operating profit after tax (NOPAT) to the total cost all its forms of capital which includes debt as well. If NOPAT exceeds the cost of capital, it gives a positive EVA and on the other hand, if the NOPAT is less than the cost of capital, it gives a negative EVA. The word capital includes all the assets invested in the firm taking into consideration the deduction of the current liabilities which are not entitled to any interest from those assets and the equity.

EVA includes cost of all the capital invested by firms calculated not following in the generally accepted accounting principles (GAAP). Cost of capital is the essential difference between accounting profit and the profit from the stand point of an economist (Ramana, 2003 [15]). Accountants never deduct the cost of capital when calculate the profit. In other words, the cost of the equity is subtracted from the revenue. On the other hand from an economist's point of view, there are charges for all the resources in computation of profit. This includes an opportunity costs for the equity capital invested by the shareholders in the business. Therefore, the calculation of economic profit is net above the cost of all resources.

Accordingly, EVA represents company's profit which is net of the cost of both debt and equity capital invested in the business (Stewart, 1994). However, Young (1997) argues that EVA has issues more than just this deduction. Young supports GAAP inexorably distort accounting profits and equity capital, even though the managers do not have any intention to manipulate the figures under the best reporting practices. In order to restore these distortions, EVA computation includes number of adjustments based on the GAAP based figures. In fact, Stewart (1991) [16] argued that about 164 adjustments needed in calculation EVA. Therefore, it is likely that EVA users are to abandon any measurement of value creation from accounting principles.

While Lehn \& Makhija (1996) [17] concluded that EVA can be exhibited as superior performance measurement tool as compared to the conventional accounting measures. The same was claimed by Stewart in 1989 when it first proposed the model. Though there are arguments in both sides for EVA for decades, this study aims to examine it and come to a conclusion.

\section{Literature Review}

Stewart (1991) comes up with the book "The Quest for Value" in which EVA is introduced as value based financial performance measure with its benefits. In order to support the concept Stewart (1994) asserts that EVA stands well out from the crowd as the single best measures of value creation on continuous basis and EVA is almost $50 \%$ better than accounting based measures in explaining changes in the shareholders wealth." Stewart (1991) further advocates EVA saying that "the best practical periodic performance measure is EVA while earnings, earnings per share, and earnings growth are misleading measures of corporate performance.” There is no single accounting measure which explains the variability in shareholders wealth (Chen \& Dodd, 1997) [18]. Sharma \& Kumar (2010) argues that the financial measure is being used in measuring financial performance is to be correlated with shareholders wealth. EVA is claimed to be the concept which gives the true economic profit of the firm and the value created for the shareholders. There are number of research conducted in the developed country and developing country which supported the superiority of EVA as financial performance measure.

Abdullah (2004) [19] argued that in Malaysia, ratios are used by the companies in order to measure the firm performance, may not be able to measure and capture the firm's value which is created over the period. Issham (2011) further states the need of a new financial measure tool in Malaysia. Issham argues that since the 1997/1998 crisis Malaysia is suffering for a most suitable performance measure tool which can help the investors in assessing value created on their investment. According the study conducted by Sharma \& Kumar (2010) there are only 23 articles published in Brazil, Russia, Indonesia, New Zealand and Malaysia over last ten years. This survey reflects that there is very minimal research conducted on EVA in Malaysia. 
Therefore, it seems that it is necessary to come up with a new performance measure tool which can depict the shareholder value and more research is required on performance measurement tool as well as on value based measures. By so far, none of the public listed firms in Malaysia have published their annual report which used EVA as performance measurement tool. In this vein, EVA can be proposed to measure firm performance, as EVA does not just explain accounting information but economy and market information.

Despite all the virtues of EVA's superiority, there are arguments against it too. Villiers (1997) [20] argued that EVA is not effective under inflation, as the concept cannot be used to estimate actual productivity. Villiers further states that the problem with EVA is, it is calculated based on accounting profit, that a discrepancy exists between accounting profit and true profit and that this disaggregation is exacerbated by inflation. There are ample of research have been conducted on EVA and articles have been published in advanced economies, research has also been emerged in developing countries. There is still debate on EVA concept though there have been a remarkable increase in research on EVA. After conducting a study on 112 articles on EVA Sharma \& Kumar (2010) concluded that it is significantly necessary to conduct research on EVA in order to signify greater empirical certainty of EVA as performance measurement tool as there is mixed evidences on the superiority of the concept. Worthington \& West (2001) [21] proposed the same. Worthington \& West argued that there is an obvious requirement to examine the usefulness of EVA over traditional measures over a longer period of time frame which would allow greater empirical certainty on EVA's status as a corporate performance measure.

\section{Why EVA}

Though EVA explains to corporate owners and managers about the wealth creation in the firm, Young (1997) argues that European corporate managers are still behind from the understanding of value creation. In fact, corporate managers still stick with the conventional financial performance measures, even though it cannot tell whether there, is value created in the business, or otherwise. Investors in particular, are entitled to be informed regarding the wealth creation of a company.

EVA is gaining popularity because each of the traditional tools only can explain a specific market or firm situation only. For example, earnings per share can only explain the capital market not the capital budgeting. Likewise, net present value cannot explain target return but it can explain only capital budgeting. On the other hand, EVA offers more than just one performance. EVA can explain capital market, capital budgeting and net assets at the same time. As a result, managers are not required to calculate three financial measures for three different performances, EVA itself can explain all three different performances.

According to Maditinos, Sevic, \& Theriou (2006), hundreds of companies in United State (US) when started to use EVA as performance measurement tool and incentive compensation system, soon it gains popularity across the United Kingdom (UK), Australia, Canada, Brazil, Germany, Mexico. For instance, in New Zealand, EVA is adopted by the state owned companies as their performance measurement tool (Worthington \& West, 2001). The most significant observation is the adoption of EVA by some of the world's giant companies such as Coca Cola, Sprint Corporation and Quaker Oats. However, Haque, Akter \& Shil, (2004) [22] argued that people are reluctant to implement new but strong performance measurement tool. In Asia including Malaysia, there has been very little factual research published on Malaysia's current position on EVA. Al-Amin \& Hossain (2004) [23] observe that not a single company use EVA as a performance measure to evaluate internally in Bangladesh. Nonetheless, concept of EVA has gained popularity all over the world particularly in US, UK and European countries as companies started to use EVA as an internal as well as external performance measure due to the fact that it is consistent with the organizational objective of shareholder's value creation (Sharma \& Kumar, 2010).

There are number of researchers who found positive results in their study on EVA and therefore have supported the theory of EVA. Subsequently, Forker \& Powell 2004 [24]; Maditinos, Sevic, \& Theriou 2006; Houle, 2008 [25]; Issham, 2010 [26]; Issham, 2011 agree with to (Stewart, 1994, pp. 75) who argues that "EVA stands well out from the crowd as the single best measure of wealth creation on a contemporaneous basis [and] is almost $50 \%$ better than its closest accounting-based competitor [Earnings per share (EPS), Return on Equity (ROE) and Return on investment (ROI)] in explaining changes in shareholder wealth". On the other hand, the traditional performance measurement tools (ROI, RONA, and ROCE, ROIC) fail to assess the true economic return of a firm, as they all are based on the historical values (Haque, Akter \& Shil, 2004). Therefore, it is argued that EVA is a financial performance measurement tool as better compared to any other tools in measuring true economic profit of a company.

A very common problem when implementing corporate governance is due to conflict of interest both owners and managers. Managers intend to work and implement such accounting principles that help them to increase their bonus and compensation plan, whereas owners want to maximize their own wealth. In view with this argument, Young (1997) asserts that the significant advantage of using EVA can help firms in resolving this agency 
problem. By implementing EVA managers will eventually also act like owners, as their wealth is linked to that of the investors. In addition, Managers have less scope to manipulate the accounting profits under EVA. On the other hand, if ROI, ROE and other traditional performance measures are used for manager's compensation plan, they are highly intended to manipulate the figures in order to maximize their own wealth.

In addition, Abdullah (2004) found that financial ratios are being used to measure the firm performance; however, ratios may not be able to measure and capture the firm's value which is created over the period. Recently, Issham (2011) proposes the need for a new financial performance measurement tool. It is argued that since the financial crisis of July 1997, Malaysia is suffering for a measurement tool that can help the investors evaluate performance. It is suggested that Malaysia needs such a measurement tool that can combine factor more than accounting, for example a tool that can explain not just accounting, economy and market information also.

The increments of EVA value in value Creator Company tend to increase accounting profit at a higher rate than in value destroyer companies (Issham, 2011). While the incentives of top management are given based on accounting figure, increased profit could be one of the main measures which increase the incentives of the management. Therefore, EVA can be used to measure the firm performance and to reward the management.

\section{Comparison between EVA and Traditional Measures}

EVA proponents assert that on important benefit of EVA is that, it adjusts reported accounting results to eliminate distortions encountered in measuring true economic performance.

Conventional performance measures are criticised such as Return On Investment (ROI), return on assets (ROA), return on equity (ROE), return on sales (ROS), or earning-per-share are deficient because they are uni-dimensional and thus unsuited to fully assessing firms' strategic accounting, firms' strategic outcomes and performance (Venktraman \& Ramanujam, 1986 [27]). They also display that they reflect only past performance and not future performance. Moreover, they argued that EVA is better goal congruence than ROI. EVA helps overcome the goal incongruence that exists between the manager and the firm which cannot be resolved using ROI.

In research conducted by Cordeiro \& Kent (2001) [28] argued that traditional accounting measures ignore differences in risk-taking between firms in their quest for profits. Managers tend to manipulate reported accounting profits for their own advantage and choose alternative accounting procedures among the GAAP framework. Some common techniques involve switching between inventory policies, switching depreciation methods, and expense on provisions.

In book "The Importance of Concept Boundaries" Morse et al., (1996) [29] mentioned that significant limitations of ROI is that it influences the managers to make investment on projects on their own interest and for the best interest of the company as a whole, while they are the people in the company who are evaluated and rewarded based on the measures.

Chen and Dodd (1997) argued that traditional accounting profits like earnings per share and return on equity are among the most commonly used performance measures are being criticized as they do not consider the total cost of capital and as for induly influencing with accrual-based accounting conventions, whereas EVA which is calculated by taking into consideration the difference between after-tax operating profits and the total cost of capital, is treated as a measure of a company's real profitability.

Furthermore, EVA allows its users to evaluate whether the return being earned on invested capital exceeds its cost as measured by the returns from alternative capital uses. As a result, management may do different things to create value for the business. No matter what the management does, if the value is created it will eventually be reflected in the EVA measure.

Adoption of EVA increased steadily as managers have become discontented with the standard of accounting measures which fail to provide helpful information in terms of decision making. Increased number to companies turned to EVA as for their performance measure to bolster their understanding and ability to achieve profitability.

Traditional performance measures have some insufficiencies in guiding to shareholders wealth maximization, as they ignore the cost of capital, such measures lack a formal mechanism for determining whether achieving such goals create values for shareholders (Yook \& McCabe, 2001) [30].

Even though, a firm generates net income and high ROI, it may still not be able to contribute to value creation for shareholders provided that the earnings fall short to cover the required returns that shareholder could earn by investing in other securities of comparable risk.

\section{EVA Adjustments}

In order not to bind EVA with conventional GAAP, Stewart (1994) suggests a series of adjustments. These include 164 adjustments to achieve the EVA that are not bound by GAAP. Though, these numbers of adjustments are varied country to country based on the corporate situation of that specific country (Weissenrieder, 1997) [31] however, in practice five to ten adjustments are adequate (Mouritsen, 1998) [32]. Studies conducted by 
Mouritse, (1998); Stern, Stewart, \& Chew, (1997) [33] and Yong, (1997) indicate that no company intended to apply all the 164 adjustments of them. It is found that only 15 to 25 adjustments are necessary. However, adjustments are recommended by the past researches only if there is any material impact on EVA.

Worthington \& Tracy (2001) asserts that the adjustments are made in two steps. Initially cost of capital is subtracted from net operating profit after tax, whereas the second steps of adjustments are the most controversial. Young (1997) proposes that most of the adjustments are in the form of what EVA's leading advocates Stern and Stewart call equity capital. There are logics given for the adjustments which indicate that, in GAAP there are number of items were charged to compute earnings in the income statement. Stewart (1994) argues all these items can mislead the capital and ultimately reduce the stated capital. Therefore, it is significant to avoid any misstatement in operating income resulting in no understatement in capital charges. The items include goodwill, provisions, research and development (R\&D), operating lease, depreciation, revenue recognition, bad debts write off, inflation, special issues for taxation, deferred taxes, valuation of contingent liabilities and hedges, currency translation and inventory costing and valuation (Maditinos, Sevic, \& Theriou, 2006). Young (1997) further proposes that companies intending to adopt EVA should limit the number of adjustments to fewer than ten; otherwise the method makes the system costly and complicated for the companies. In fact, Young (1997; 1999 [34]) claims that a large number of adjustments are having little importance to the company. Therefore, adjustments should be made provided that the amount is material or significant, and the information is as well. The following discusses the adjustments needed for EVA.

\subsection{Provisions}

Provision is a very common account created in companies. Provision includes costs for warranties and guarantees, environmental damage, sick leave, doubtful debts and likewise. In preparing the financial statements, provisions charges are recorded immediately rather than the time provisions are incurred and paid out. According to GAAP, companies are entitled to make the provision account; however, GAAP suggests that the account is conservative because of its characteristics. Provisions are considered will be paid in future when they are incurred, whereas computation is made immediately the account it created.

Young (1997) argues that provision creates opportunities for the corporate managers for manipulating the profits. For instance, when the company is making large amount of profit, managers can create bulky provision account which helps to understate the profit for that spe- cific year resulting a reserve account which can be used in subsequent years to boost the profit, while the company performance is inadequate. Such acts are well accepted in corporate globe. However, as EVA is not locked by conventional GAAP, company intends to adopt EVA can provide a few adjustments by adding back the provisions to operating income, when it is shown increased during the year and decreases in provision by subtracting from the reported profit. Therefore, the suggested adjustment will correct the manipulation made in GAAP numbers. It further states that the balance in the provisions account should be added back to invested capital.

\subsection{Research and Development (R\&D)}

According to GAAP all R\&D costs are considered as expense when incurred. There are ample of amount is invested for R\&D every year in companies. Therefore, if this huge amount is not capitalised, it understates equity capital while overstating EVA. It helps to increase the value creation for its shareholders, whereas while in reality value is not created rather destroyed.

EVA suggests adding back the R\&D cost to capital and operating profit and writing down the cost arise from the product or services developed from the research as it goes on based on the number of expected usage period. In fact, Young (1997) suggests amortising the R\&D cost over an arbitrary period.

\subsection{Operating Leases}

Fixed assets are often acquired through leasing. Acquisition of lease assets includes machineries, land, building, property and plants. Young (1997) argues that leasing provides further security to lease of assets. Operating lease enables company to structure the lease contract so as they can keep off the debt from balance sheet. In accounting this method is considered as rent. Lease payment in GAAP, is treated as rent payment. Therefore, Acquired assets under leasing agreement are not capitalised.

However, such a treatment understates the operating profit as the lease payment is treated as rent payment, resulting understated assets and invested capital. Therefore, EVA requires an adjustment which is made using method that requires, the present value of future cash flow of lease should be added to invested capital and the operating profit. However, the interest expense is calculated by multiplying the same value as added to invested capital of the lease by the borrowing rate.

\subsection{Goodwill}

Goodwill is generated when a company acquires another company. Goodwill is the difference between price paid and the assets acquired. If the fair value of the assets net 
of liabilities exceeds the price paid off by the acquirer to the acquiree, is treated as goodwill. The Australian Accounting Standard Board requires amortisation of goodwill. Therefore, this written down method of goodwill varies from country to country. In the UK the accounting board requires the goodwill to be written down immediately.

However, EVA advocates that written down method is wrong both for immediate write off and amortisation of goodwill over a number of years. This is because writing down goodwill; it removes a portion of the investment from balance sheet. Hence, it understates the equity capital. Therefore, EVA recommends adjustments of the written down goodwill, so as the EVA is not overstated resulting a misleading increased value to shareholders. In order to avoid such misstatements, EVA requires any amortisation or immediate write down of goodwill; add back to capital account and operating profit. Furthermore, if there was any goodwill written off in the prior years, EVA requires add back of that cumulative amortisation from prior years to the capital Young (1997).

From the above discussion though 164 adjustments are suggested that companies adopt EVA should limit the number of adjustments not more than ten. This is because the more the adjustments are made the more complicated system is made. Research has also found that some companies do not make any adjustments at all in order to make the system more understandable and easier to increase communication between the management and shareholders.

\section{Critics of EVA and Arguments against Those Critics}

Weissenrieder (1997) quested on the feasibility of EVA as financial performance measure. This researcher argues that even if it is possible to make all 164 adjustments, it will not function well enough. Therefore, in reality, is it possible to implement EVA as financial performance measure?

Ray (2001) [35] suggests that the giants in the corporate globe like DuPont, Eli Lilly, Coca-Cola, AT\&T, Briggs-Stratton and many others have implemented this new financial performance measure, EVA. It is reported that not all the adjustments are done but depending of the materiality and availability of required information adjustments are made. All of them reported significant financial improvements in their performance. According to Ray Coca-Cola, the earliest user of EVA reported increase in stock price. In 1981 Coca-Cola implemented EVA as their performance measure tool and reported an increase in stock price from \$3 (on a slit-adjusted basis) to over $\$ 60$. Therefore, Weissenrieder (1997) argues that EVA can be adopted as financial performance measure by companies by making the necessary adjustments.
On the other hand, Anne (2005) claimed that they could not find any theoretical or empirical evidence wrong accounting numbers were corrected by EVA adjustments in order to get the correct value. There is no economic theory, which can guide to select the most relevant accounting variables that will be adjusted.

Chen \& Dodd (1997) cited that, though accounting profits for example earnings per share, return on investment and return on equity are among the most commonly used performance measures; they are strongly criticized for not taking into consideration the total cost of capital and for being unduly influenced by accrual based accounting conventions. In contrast, EVA, the difference between after-tax operating profits and the total cost of capital, is promoted as a measure of a company's real profitability.

\section{Eva and Its Status in Malaysia}

According to Maditinos, Sevic, \& Theriou (2006) EVA is interesting to study and adoption of it is not just with the hundreds companies in US as performance measurement tool and incentive compensation system, but it gained popularity and is used in UK, Australia, Canada, Brazil, Germany, Mexico. In New Zealand EVA is adopted by the state owned companies as their performance measurement tool (Worthingyon \& West, 2001). Haque, Akter \& Shil, (2004) argue that the corporate giants such as DuPont, Eli Lilly, Coca-Cola, AT\&T, Briggs-Stratton and many others have adopted this new financial tool and in many instances, reported significantly financial improvements.

Basically the concept of EVA is relatively new (especially in Malaysia) and not many studies have been conducted in Malaysia as conventional financial measures are still widely used by most of the corporations instead of EVA. Studies conducted in Malaysia by scholars including Ismail (2010; 2011) on EVA, none of them reported that the companies reported EVA in their financial statement as performance measure. Moreover, it has found that even the companies do not use it as their internal evaluator. Voluntary disclosure is still very infrequent in Malaysian corporate world, people are much cautious to abide by the legal mandates. As far as the large corporations are concerned, it is a matter of time and intention for the calculation and disclosure of EVA. (Haque, Akter \& Shil, 2004).

\section{Empirical Evidence}

Several authors like Young (1997); Issham et al. (2008) [36], and Silverman (2010) [37] used the model of EVA developed by Stern and Stewart to inspect the creation of value to shareholders. However, there were some variation in the explanation and calculations by different au- 
thors from which four of them are mentioned in this paper.

Young (1997), base model says that companies can use EVA to measure performance at any level of the business firms either department or division wise, not just at the group level.

This researcher calculated EVA using the following formula:

Net Sales - Operating Expenses (all operating expense including tax)

$$
=\text { Operating Profit }- \text { Capital Charges }
$$$$
=\mathrm{EVA}
$$

Capital Charges are calculated by multiplying the weighted average cost of capital (WACC) with the company's invested capital. This generates unadjusted form; EVA is equivalent to what generates by subtracting cost of capital from net income and that is called economic profit which is residual income from accountant's perspective (Young, 1997). The only difference between EVA and residual income are solely the accounting adjustments based on company's GAAP based financial statements. However in this paper EVA will be adjusted based on GAAP figures.

This author further adds that invested capital includes company's all financing besides liabilities (accounts payable, accrued wages, which is non-interesting bearing, and accrued taxes). Invested capital includes owner's equity, long term and short term all interest bearing debts. However, there is alternative way to calculate the capital, which net assets calculated by subtracting all operating liabilities from total assets. Net assets are treated as investment on which investors expect returns delivered by the managers. Value is created only if the return generated by using the net assets surpasses the cost of capital.

Issham et al. (2008), defined EVA as the dollar amount of charges for capital (both debt and equity) are subtracted from the dollar amount of net operating after tax (NOPAT) net operating after tax, calculated figure is multiplied with the percentage of weighted average coat capital. Issham et al. further state that EVA is an estimate of the amount by which earning exceeds or fall short of the rate of return shareholders could get by investing in other securities of comparable risk and includes a charge against profit for the cost of all capital a firm employs.

Issham et al. calculated EVA as follows:

EVA $=$ NOPAT - (WACC X Invested Capital).

NOPAT $=$ Profit $\&$ Loss before Tax + Interest Expense - Income Taxes - Tax Shield on Interest (Tax Rate $\mathrm{X}$ Interest Expense)

Invested Capital $=$ Short Term Debt + Long Term Debt + Minority Interest + Share holders Equity ${ }^{2}$

WACC $=$ Cost of Debt $\times\{$ Total Debt/(Total Debt + CMVE $)\} \times(1-$ Tax $)+[$ Cost of Equity $\times\{($ CMVE/(Total Debt + CMVE) $\}]^{3}$

CMVE $=$ Company's Share Price $\times$ Total Shares Out standing.

Market Value of Company = CMVE + Total Debt + Minority Interest.

Cost of Equity is calculated by using CAPM Model4.

Taking into consideration all the costs and benefits offered by the EVA system, Issham has decided to perform the calculations for the further research based on Malaysian public listed company's financial outcomes using the Young (1997) model. The reason for choosing this model is the most used and accepted model in US and Europe. Young's model showed the mostly used adjustments, which can be easily implemented based on the availability of the information.

\section{Conclusions}

EVA has been adopted by the advanced economies as financial performance measurement tool and corporate strategy which helped EVA to be identified as an important financial performance measurement tool over the conventional tools around the world. Though, there are mixed evidences on the superiority of EVA (Sharma \& Kumar, 2010), EVA has gained attention of corporate giants based on what EVA can be acclaimed to be the most recent and exciting innovation in company performance measures. There are very little evidences against the superiority of EVA over conventional financial performance measurement tools, which were defended in this paper. Though there are mixed evidences on EVA to be considered as the superior performance measure it has been claimed that the concept is the most useful measure of corporate performance (Chen \& Dodd, 1997). There is a scope for future research on EVA by taking the data of Malaysian public listed company for a particular time duration which will help to test the viability of the concept on the context of Malaysian business.

The reason that drives into working on this paper is due the state of knowledge in this area. It is aimed that it will give at least a basic idea of EVA and also explains correlation between financial parameters and stock return related to Malaysian business environment. Moreover, it would be an opportunity to enhance knowledge and share with the audience and company management who are interested to make a move from the conventional financial performance measure to EVA.

\section{REFERENCES}

[1] P. Erasmus, "Value Based Financial Performance Measures: An Evaluation of Relative and Incremental Information Content," Corporate Ownership \& Control, Vol. 6, No. 1, 2008, pp. 66-77.

[2] D. Maditinos, Z. Sevic and N. Theriou, "A Review of the Empirical Literature on Earnings and Economic Value Added (EVA) in Explaining Stock Market Returns. Which 
Performance Measure Is More Value Relevant in the Athens Stock Exchange (ASE)?” Annual Conference of the Hellenic Finance and Accounting Association Thessaloniki, 15-16 December 2006, Kevala, pp. 1-38.

[3] W. Fredrik, "Value Based Management: Economic Value Added or Cash Value Added?” Corporate Ownership \& Control, Vol. 6, No. 1, 1997, pp. 66-77.

[4] J. Grant, "Foundations of Economic Value Added," 2nd Edition, John Wiley \& Sons, New York, 2003.

[5] A. C. Worthington and T. West, "Economic Value-Added: A Review of the Theoretical and Empirical Literature," Asian Review of Accounting, Vol. 9, No. 1, 2001, pp. 6786. doi:10.1108/eb060736

[6] I. Issham, "Company Performance in Malaysia after the 1997 Economic Crisis: Using Economic Value Added (Eva) as a Predictor," African Journal of Business Management, Vol. 5, No. 7, 2011, pp. 3012-3018.

[7] M. Anne, A. M. Anderson, R. P. Bey and C. S. Weaver, "Economic Value Added Adjustments: Much to Do about Nothing?” 2005.

http://www.lehigh.edu/ incbeug/Attachments/Anderson\% 20EVA\%204-7-05.pdf.

[8] C. Elliot and T. Kay, "An Introduction to Merchandize," Thomas Cadell, London, 1777.

[9] A. Marshall, "Principles of Economics," MacMillan \& Company, New York, 1890.

[10] M. Geyser and I. E. Liebenberg, "Creating a NEW Value Tool for South African Agricultural Co-operatives," Agrekon, Vol. 42, No. 2, 2003, pp. 106-115.

[11] W. D. Dagogo and G. W. Ollor, "The Effect of Venture Capital Financing on the Economic Value Added Profile of Nigerian SMEs," African Journal of Accounting, Economics, Finance and Banking Research, Vol. 5. No. 5. 2009, pp. 37-51.

[12] D. Young, "Economic Value Added: A Primer for European Managers,” European Management Journal, Vol. 15, No. 4, 1997, pp. 335-343. doi:10.1016/S0263-2373(97)00014-5

[13] K. A. Sharma and S. Kumar, "Economic Value Added (EVA)-Literature Review and Relevant Issues,” International Journal of Economics and Finance, Vol. 2, No. 2, 2010, pp. 200-220.

[14] G. B. Stern, “EVA: Fact and Fantasy,” Journal of Applied Corporate Finance, Vol. 7, No. 2, 1994, pp 71-87. doi:10.1111/j.1745-6622.1994.tb00406.x

[15] V. D. Ramana, "Market Value Added and Economic Value Added: Some Empirical Evidences,” Bhuabneswar, Mumbai, 2005, pp. 1-15.

[16] G. B. Stern, "The Quest for Value: A Guide for Senior Managers,” Harper Business, New York, 1991.

[17] K. Lehn and A. K. Makhija, "EVA and MVA as Performance Measures and Signals for Strategic Change," Strategy \& Leadership, Vol. 24, No. 3, 1996, pp. 34-38. doi:10.1108/eb054556

[18] S. Chen and J. L. Dodd, "Economic Value Added: An Empirical Examination of a New Performance Measure,” Journal of Management Issues, Vol. 9, No. 3, 1997, pp. 301-336.
[19] S. N. Abdullah, "Board Composition, CEO Duality and Performance among Malaysian Listed Companies," Corporate Governance, Vol. 4, No. 4, 2004, pp. 47-61. doi:10.1108/14720700410558871

[20] J. D. Villiers, "The Distortions in Economic Value Added (EVA) Caused by Inflation,” Journal of Economics and Business, Vol. 49, No. 3, 1997, pp. 285-300. doi:10.1016/S0148-6195(97)00001-5

[21] A. C. Worthington and T. West, "Economic Value-Added: A Review of the Theoretical and Empirical Literature," Asian Review of Accounting, Vol. 9, No. 1, 2001, pp. 67-86. doi:10.1108/eb060736

[22] M. Haque, M. Akter and N. C. Shil, "Value-Based Measure: An Application of Eva in Small Manufacturing Company in Bangladesh," Munich Personal RePEc Archive, No. 7711, 2004, p. 12. http://mpra.ub.uni-muenchen.de/7711/

[23] A. Amin and D. M. Hossain, "Economic Value Addition: From Stakeholders Point of View," The Bangladesh Accountant, 2004, pp.106-108.

[24] J. Forker and R. Powell, "Does EVA Beat Earnings? Evidence on Associations with Stock Returns and Firm Values-Revisited,” EAA Meeting, Prague, 1-3 April 2004, pp. 301-336.

[25] M. Houle, “Economic Value Added,” Liberty University, Lynchburg, 2008.

[26] I. Issham, "Performance of Public-Listed Companies in Malaysia: Using EVA,” 2010.

[27] N. Venkatraman and R. Vasudevan, "Measurement of Business Performance in Strategy Research: A Comparison of Approaches,” Academy of Management Review, Vol. 11, No. 4, 1986, pp. 801-814.

[28] J. J. Cordeiro, and D. D. Kent Jr., "Do EVA Adopters Outperform Their Industry Peers? Evidence from Security Analyst Earnings Forecasts," American Business Review, Vol. 19, No. 2, 2001, pp. 57-63.

[29] J. M. Morse, H. E. Judith, M. Carl and E. Lenz, “Concept Analysis in Nursing Research: A Critical Appraisal," Research and Theory for Nursing Practice, Vol. 10, No. 3, 1996, pp 253-277.

[30] K. C. Yook and G. M. McCabe, "MVA and the CrossSection of Expected Stock Returns," Journal of Portfolio Management, Vol. 27, No. 3, 2001, pp. 75-87. doi:10.3905/jpm.2001.319803

[31] F. Weissenrieder, "Value Based Management: Economic Value Added or Cash Value Added?” Gothenburg Studies in Financial Economics, Working Paper Series 971214, 1997, pp. 1-42.

http://papers.ssrn.com/sol3/papers.cfm?abstract_id=1562 88

[32] J. Mouritsen, "Driving Growth: Economic Value Added versus Intellectual Capital,” Management Accounting Research, Vol. 9, No. 46, 1998, pp. 461-482.

[33] M. J. Stern, B. Stewart, H. D. Chew and Stern Stwart \& Co., "The EVA Financial Management System," Journal of Applied Corporate Finance, Vol. 8, No. 2. 1997, pp. 474-488.

[34] D. Young, "Some Reflections on Accounting Adjustments and Economic Value Added," Journal of Financial Statement Analysis, Vol. 4, No. 2, 1999, pp. 7-19. 
[35] R. Ray, "Economic Value Added: Theory, Evidence, a Missing Link,” Review of Business, Vol. 22, No. 1-2, 2001, pp. 66-70.

[36] I. Issham, A. S. M. Fazilah, Y. S. Hwa, A. A. Kamil, A. A. Ayub and M. A. Ayub, "Economic Value Added (EVA) as a Performance Measurement for GLCs vs Non-GLCs: Evi- dence from Bursa Malaysia,” Prague Economic Papers, 2008, pp. 168-179.

[37] I. H. Silverman, "Valuing Technology Stocks with EVA: A Bridge Too Far?” Journal of Business Case Studies, Vol. 6, 2010. 